\title{
Comparison of in-vitro production of progestagens by the corpora lutea of early pregnancy of the rat and hamster*
}

\author{
Yuichi Wada* and G. S. Greenwald \\ Department of Physiology, Ralph L. Smith Research Center, University of Kansas Medical Center, \\ Kansas City, Kansas 66103, U.S.A.
}

\begin{abstract}
Summary. Immature rats and adult hamsters were killed on Days 2, 4 or 8 of pregnancy (Day $1=$ sperm positive vaginal smear). Dispersed luteal cells $\left(5 \times 10^{4}\right.$ cells) were incubated for $2 \mathrm{~h}$ in the absence or presence of graded doses of ovine LH. In the absence of $\mathrm{LH}$, incubation of rat luteal cells compared to hamster cells produced about 3-6-fold as much progesterone, 26-66 times as much $20 \alpha$-dihydroprogesterone and about the same amounts of $17 \alpha$-hydroxyprogesterone. For the rat, $1 \mathrm{ng} \mathrm{LH}$ was the minimal dose which stimulated synthesis of progesterone and $17 \alpha$-hydroxyprogesterone by luteal cells on Days 2 and 4 whereas $10 \mathrm{ng}$ LH stimulated maximal production of progesterone by Day-8 luteal cells. As pregnancy progressed from Day 2 to Day 8 , there was an inverse relationship between the levels of progesterone and $20 \alpha$-dihydroprogesterone accumulated by rat luteal cells. For the hamster, $1 \mathrm{ng}$ LH significantly stimulated accumulation of progesterone and $17 \alpha$-hydroxyprogesterone by Day- 2 luteal cells but not by Day- 4 or Day- 8 cells. Hamster luteal cells on Day 4 produced the highest levels of progesterone in response to 10 or $100 \mathrm{ng} \mathrm{LH}$, with a maximal rate of accumulation by Day-8 cells with $10 \mathrm{ng} \mathrm{LH}$.
\end{abstract}

\section{Introduction}

Luteinizing hormone (LH) is an important luteotrophic hormone in many species (for references see Greenwald \& Rothchild, 1968; Hilliard, 1973; Hansel, Concannon \& Lukaszewska, 1973). The critical need for LH for the maintenance of pregnancy in the rat and hamster has been demonstrated in several studies using hypophysectomized animals or animals treated with antiserum to LH. In the rat, the corpora lutea (CL) of pregnancy are dependent on LH between Days 8 and 11 (Madhwa Raj \& Moudgal, 1970; Morishige \& Rothchild, 1974) and in the hamster LH is required between Days 4 and 10 (Jagannadha Rao, Madhwa Raj \& Moudgal, 1972; Mukku \& Moudgal, 1976; Terranova \& Greenwald, 1979a). Although prolactin and FSH are considered essential luteotrophins for the hamster, suitable concentrations of $\mathrm{LH}$ are also needed for optimal luteal steroidogenesis (Greenwald, 1967).

It is well known that $20 \alpha$-dihydroprogesterone is a major metabolite of progesterone in the pregnant rat (Wiest, 1970). The CL of the pregnant hamster also produce $20 \alpha$-dihydroprogesterone but in small amounts (Shaha \& Greenwald, 1982). The purpose of the present study was to compare the direct acute effects of $\mathrm{LH}$ on dispersed luteal cells in pregnant rats and hamsters by measuring the secretion of 3 progestagens.

* Reprint requests to Dr G. S. Greenwald.

$\dagger$ Present address: Department of Obstetrics and Gynecology, Tohoku University School of Medicine, 1-1 SeiryoMachi, Sendai 980, Japan.

(C) 1984 Journals of Reproduction \& Fertility Ltd 


\section{Materials and Methods}

Animals. Immature female rats of the Holtzman strain and mature female golden hamsters were maintained on a $14 \mathrm{~h}$ light : $10 \mathrm{~h}$ dark schedule (lights on $05: 00-19: 00 \mathrm{~h}$ ). The rats were given an s.c. injection of 7 i.u. PMSG (NIAMDD-PMSG-2) on the morning of Day 26. At 28 days of age, at $16: 00 \mathrm{~h}$, the females were caged with adult males ( 3 males:2 females). The presence of spermatozoa in the vaginal lavage the next morning was considered to indicate Day 1 of pregnancy. At least 3 consecutive 4-day oestrous cycles were monitored in the hamsters before they were caged overnight with males. A sperm-positive vaginal smear was taken as Day 1 of pregnancy. Between $09: 00 \mathrm{~h}$ and $10: 00 \mathrm{~h}$ on Days 2, 4 or 8 of pregnancy, the animals were decapitated, blood collected and allowed to clot. After centrifugation, serum was stored at $-20^{\circ} \mathrm{C}$ until used in steroid radioimmunoassays. Pregnancy was confirmed by the presence of embryos in oviducal or uterine flushings or the presence of implantation sites.

Dispersion and incubation of luteal cells. Immediately after blood collection, the ovaries were removed and placed in Medium 199 (with 25 mM-Hepes buffer; Gibco, Grand Island, NY). Corpora lutea were dissected and freed of adherent non-luteal tissue. The dispersion technique was adapted from a previously described method (Sala, Dufau \& Catt, 1979). Corpora lutea collected and pooled (about 60-70 CL) from 6-7 rats or hamsters on Day 2, 4 or 8 of pregnancy were finely minced and incubated in $5 \mathrm{ml}$ Medium 199 containing $0.2 \%$ collagenase (type $\mathrm{V}, 240$ i.u./mg; Sigma, St Louis, MO) at $37^{\circ} \mathrm{C}$ and shaken at $80 \mathrm{cycles} / \mathrm{min}$ to dissociate the cells. After $30 \mathrm{~min}$ the old medium was discarded and $5 \mathrm{ml}$ fresh Medium 199 containing $0.2 \%$ collagenase was added. After incubation for 60-90 min, the medium was transferred to another tube $(12 \times 75 \mathrm{~mm})$ and the cells were dispersed by aspiration using a fine Pasteur pipette. The contents were allowed to stand for $1 \mathrm{~min}$ to allow tissue fragments to settle. The supernatant was then removed and saved and fresh medium was added to the sediment. This dispersion procedure was repeated 3 times. The pooled supernatant was centrifuged at $150 \mathrm{~g}$ for $6 \mathrm{~min}$ at room temperature. The cell pellets were washed twice with fresh Medium 199 and the cells were finally resuspended in the same medium. Approximately $5 \times 10^{4}$ viable cells were incubated at $37^{\circ} \mathrm{C}$ in a plastic tube $(12 \times 75 \mathrm{~mm})$ containing $1 \mathrm{ml}$ Medium 199 with or without ovine LH (NIH ovine LH-S22, $0 \cdot 1-100 \mathrm{ng} / \mathrm{ml}$ ). After a $2-\mathrm{h}$ incubation, the medium and cells were snap frozen and stored at $-20^{\circ} \mathrm{C}$. Cell viability was checked by the trypan blue exclusion method (Tennant, 1964) and at the beginning and end of incubation was always more than $85 \%$.

Assays. The procedures for the radioimmunoassays of steroids were as described by Shaha $\&$ Greenwald (1982). The antiserum for the progesterone assay was provided by Dr A. H. Surve (Sandoz, Inc., New Jersey), the antiserum to $20 \alpha$-dihydroprogesterone was from Dr C. N. Pang and Dr J. Hilliard (UCLA) and the antiserum to $17 \alpha$-hydroxyprogesterone was purchased from Steranti Research Ltd (Hertfordshire, U.K.). For assay of serum progesterone, $17 \alpha$-hydroxyprogesterone and $20 \alpha$-dihydroprogesterone, 2, 25 and $2 \mu \mathrm{l}$ rat serum and 10,25 and $25 \mu \mathrm{l}$ hamster serum were used, respectively. For measurements of steroids in the incubation medium plus cell samples, 5-20, 200 and 5-200 $\mu \mathrm{l}$ were used for the progesterone, 17 $\alpha$-hydroxyprogesterone and $20 \alpha$ dihydroprogesterone assays, respectively. The lower limit of assay sensitivity for all three steroids was $5 \mathrm{pg} /$ tube. The inter-assay coefficient of variation was $6 \cdot 6 \%$ for progesterone, $9 \cdot 1 \%$ for $20 \alpha$ dihydroprogesterone and $7.7 \%$ for $17 \alpha$-hydroxyprogesterone. The intra-assay coefficient of variation was $<5 \%$ for all three steroids. The cross-reactivity of the antiserum to $20 \alpha$-dihydroprogesterone was $0.18 \%$ with progesterone and $0.03 \%$ with $17 \alpha$-hydroxyprogesterone. The crossreactivity of the antiserum to $17 \alpha$-hydroxyprogesterone was $0.1 \%$ with $20 \alpha$-dihydroprogesterone. Serum from an adrenalectomized male rat contained $<1 \mathrm{ng} / \mathrm{ml}$ of all three steroids.

Statistics. The significance of the difference between two means was tested by Student's $t$ test, but when more than two means were compared analysis of variance was carried out and the 
significance of the difference between means was determined by Duncan's multiple range test. Differences were judged significant if $P<0.05$.

\section{Results}

Serum concentrations of progestagens on Days 2, 4 and 8 of pregnancy

Rat. Serum progesterone and $17 \alpha$-hydroxyprogesterone concentrations increased significantly between Days 2 and 4 (Table 1) but were unchanged on Day 8 . Although the levels of serum $20 \alpha-$ dihydroprogesterone on Days 4 and 8 were slightly reduced compared to the value on Day 2 , the differences were not significant.

Hamster. The serum levels of all three progestagens were considerably lower than in the pregnant rat. Serum progesterone and $17 \alpha$-hydroxyprogesterone concentrations gradually increased from Day 2 until Day 8 and progesterone values on Day 8 were higher than those on Days 2 and 4 (Table 1$)$.

Table 1. Serum concentrations of progestagens on Days 2, 4 and 8 of pregnancy in the rat and hamster

\begin{tabular}{|c|c|c|c|c|c|c|}
\hline \multirow[b]{2}{*}{$\begin{array}{l}\text { Day of } \\
\text { pregnancy }\end{array}$} & \multicolumn{3}{|c|}{ Rat } & \multicolumn{3}{|c|}{ Hamster } \\
\hline & $\begin{array}{l}\text { Progesterone } \\
\text { (ng/ml) }\end{array}$ & $\begin{array}{l}20 \alpha \text {-Dihydro- } \\
\text { progesterone } \\
(\mathrm{ng} / \mathrm{ml})\end{array}$ & $\begin{array}{l}\text { 17 } \alpha \text {-Hydroxy- } \\
\text { progesterone } \\
(\mathrm{ng} / \mathrm{ml})\end{array}$ & $\begin{array}{l}\text { Progesterone } \\
\text { (ng/ml) }\end{array}$ & $\begin{array}{l}20 \alpha \text {-Dihydro- } \\
\text { progesterone } \\
(\mathrm{pg} / \mathrm{ml})\end{array}$ & $\begin{array}{l}17 \alpha-\text { Hydroxy- } \\
\text { progesterone } \\
(\mathrm{pg} / \mathrm{ml})\end{array}$ \\
\hline 2 & $21 \cdot 0 \pm 4 \cdot 5(5)$ & $44 \cdot 9 \pm 4 \cdot 1(4)$ & $3 \cdot 2 \pm 0 \cdot 2(4)$ & $7 \cdot 2 \pm 0 \cdot 9(5)$ & $491 \pm 99(5)$ & $894 \pm 114$ \\
\hline 4 & $51.0 \pm 4.5(5) \dagger$ & $33.8 \pm 6.2(5)$ & $6.6 \pm 1.2(5)^{*}$ & $8.9 \pm 0.7(6)$ & $469 \pm 80(5)$ & $1012 \pm 134(6)$ \\
\hline 8 & $57.1 \pm 5.8(5)$ & $38 \cdot 2 \pm 2 \cdot 6(5)$ & $7.7 \pm 0.9$ & $11 \cdot 3 \pm 0.4(5)^{*}$ & $664 \pm 91(6)$ & $1278 \pm 39(5)$ \\
\hline
\end{tabular}

Values are mean \pm s.e.m. for the number of animals indicated in parentheses.

Significantly different from previous value: ${ }^{*} P<0.05, \dagger P<0.01$.

\section{Response of dispersed luteal cells to $\mathrm{LH}$}

Rat. In the absence of $\mathrm{LH}$ the basal accumulation of progesterone, $20 \alpha$-dihydroprogesterone and $17 \alpha$-hydroxyprogesterone by dispersed luteal cells was 4-7.5 $\mathrm{ng}, 2.5-8 \mathrm{ng}$ and $150-200 \mathrm{pg}$, respectively. All 3 progestagens were stimulated by the addition of LH on Day 2, 4 or 8 (Text-fig. 1a). In general, the response patterns to $\mathrm{LH}$ were similar between progesterone and $17 \alpha-$ hydroxyprogesterone and inversely related between progesterone and $20 \alpha$-dihydroprogesterone.

Hamster. The basal accumulation of progesterone and $20 \alpha$-dihydroprogesterone by luteal cells from pregnant hamsters was considerably reduced compared to the response of the rat luteal cells whereas $17 \alpha$-hydroxyprogesterone values were similar. The hamster luteal cells accumulated $20 \alpha-$ dihydroprogesterone at about half the level of $17 \alpha$-hydroxyprogesterone and the 'inverse staircase' relationship between progesterone and $20 \alpha$-dihydroprogesterone levels that was conspicuous in the rat did not exist for the hamster luteal cells.

\section{Discussion}

We used immature rather than adult pregnant rats because synchronous ovulation and mating are readily produced in the prepubertal animal and all the characteristics of the ensuing gestation are comparable to those in adults (Nutti, Sridharan \& Meyer, 1975). Moreover, concentrations of serum progesterone and $20 \alpha$-dihydroprogesterone in immature pregnant rats on Days 2,4 and 8 (Table 1) are similar to values in adult pregnant animals of the same strain (Taya \& Greenwald, 1981). 
(a) RATS

(b) HAMSTERS

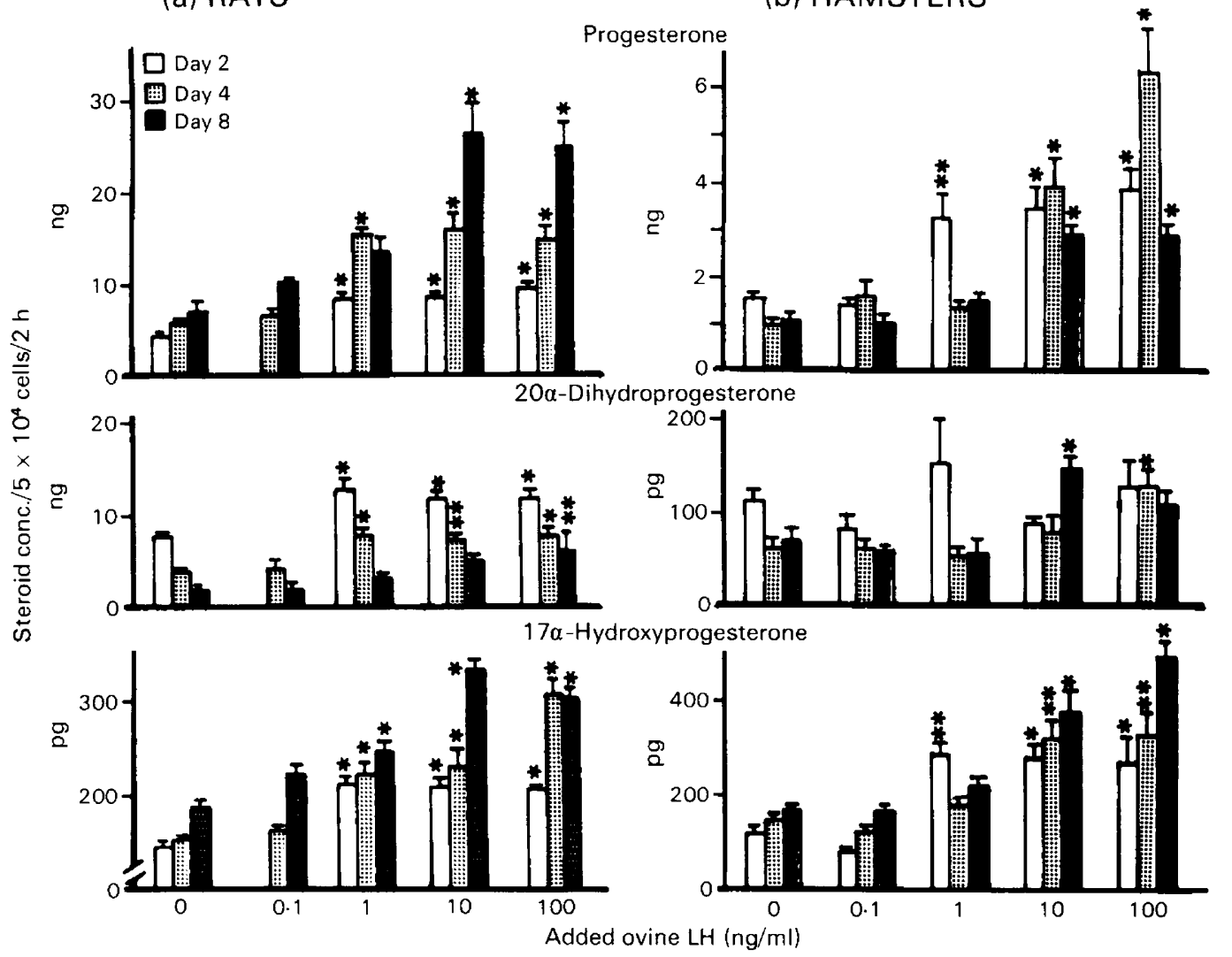

Text-fig. 1. The response of dispersed luteal cells from (a) pregnant rats and (b) pregnant hamsters to LH. Approximately $5 \times 10^{4}$ luteal cells were incubated in $1 \mathrm{ml}$ Medium 199 for $2 \mathrm{~h}$ with or without various concentrations of ovine $\mathrm{LH}$. The accumulation of progestagens in medium and cells is expressed as the mean \pm s.e.m. of 6-8 (basal levels) or 4-5(LH) replicates.

${ }^{*} P<0.05,{ }^{* *} P<0.01$ compared with basal levels of the same progestagen.

Serum progestagen values are considerably higher in pregnant rats than in hamsters, with the most striking disparity in the level of $20 \alpha$-dihydroprogesterone (Table 1). In pregnant rats, the serum concentration of progesterone is proportional to the number and weight of CL (Elbaum, Bender, Brown \& Keyes, 1975). In the present study, on Day 8 of pregnancy each CL weighed 1.3$1.5 \mathrm{mg}$ in the rats and $0.8 \mathrm{mg}$ in the hamsters. However, luteal mass alone cannot account for the species differences in serum progestagen values; differences in the capacity of the luteal cells to secrete progesterone obviously contribute (Text-fig. 1).

With the same approximate number of luteal cells incubated for both species, basal accumulation of 17 $\alpha$-hydroxyprogesterone was similar but the rat luteal cells secreted much more progesterone and especially $20 \alpha$-dihydroprogesterone than did those of the hamster. The factors accounting for this difference are unknown, but possibilities include differences in receptor numbers, binding affinity, rate-limiting steps in steroidogenesis, and interaction with other peptide or steroid hormones. In the rat, 1-2-day-old CL have few LH receptors, but there is a gradual increase in numbers over the next few days (Lee, Tateishi, Ryan \& Jiang, 1975), influenced by the levels of prolactin (Grinwich, Hichens \& Behrman, 1976). In the present study, $1 \mathrm{ng}$ LH was the minimal effective dose for stimulating progestagen synthesis by rat luteal cells on Days 2 and 4 , and 10 or $100 \mathrm{ng} \mathrm{LH}$ did not stimulate further increases (Text-fig. 1a). On the other hand, the luteal cells on Day 8 of pregnancy responded maximally to $10 \mathrm{ng} \mathrm{LH}$ in synthesizing progesterone and $17 \alpha$ - 
hydroxyprogesterone. Rat luteal cells showed a clear-cut inverse relationship between the accumulation of progesterone and $20 \alpha$-dihydroprogesterone which was especially pronounced on Day 8 , in the absence or presence of LH.

In the hamster, the ability of dispersed luteal cells to accumulate progesterone in response to $\mathrm{LH}$ was maximal on Day 4 of pregnancy and unlike the rat this capacity was reduced on Day 8 (Textfig. 1b). For the pseudopregnant hamster, specific binding of hCG to luteal tissues is drastically reduced between Day 7 and 8 , coinciding with the fall in serum progesterone to undetectable levels (Harris, Murphy \& Grinwich, 1981). When Day-8 pregnant or pseudopregnant hamsters are injected with antiserum to $\mathrm{LH}$, the fall in progesterone is much more precipitous in the pseudopregnant animals, suggesting that placental luteotrophic factors are already operative in support of luteal secretion of progesterone (Terranova \& Greenwald, 1979b). This is also substantiated by the fact that serum levels of progesterone were higher on Day 8 than Day 4 (Table 1) despite the decreased in-vitro responsiveness of Day- 8 luteal cells to $100 \mathrm{ng}$ LH compared to the Day-4 luteal cells (Text-fig. 1 b). Therefore, occupancy of a portion of the LH receptor population of the Day- 8 CL by a placental chorionic gonadotrophin may account for the decreased responsiveness in vitro to a pituitary $\mathrm{LH}$ preparation. The present in-vitro findings reaffirm that $20 \alpha$-dihydroprogesterone is a minor metabolite in the hamster (Shaha \& Greenwald, 1982), values being $0 \cdot 1 \mathrm{ng} / 5 \times 10^{4} \mathrm{cells} / 2 \mathrm{~h}$ compared to $3-10 \mathrm{ng}$ in the rat (Text-fig. 1). On the other hand, $17 \alpha$-hydroxyprogesterone is produced to the same extent in both species. In vitro, the CL of pregnancy of the rat and hamster are able to produce the same amounts of oestradiol in the absence or presence of exogenous testosterone (Greenwald, Voogt \& Limback, 1984). Therefore, beyond the species differences in rates of luteal production of progesterone and $20 \alpha$-dihydroprogesterone, C19 and C18 steroid production appears to be similar in the hamster and rat.

Y.W. was supported by a fellowship from the Ford Foundation. The research was supported by NIH grant HD00596 (G.S.G.). We thank the National Hormone and Pituitary program (NIADDK) for providing the ovine $\mathrm{LH}$.

\section{References}

Elbaum, D.J., Bender, E.M., Brown, J.M. \& Keyes, P.L. (1975) Serum progesterone in pregnant rats with ectopic or in situ corpora lutea: correlation between amount of luteal tissue and progesterone concentration. Biol. Reprod. 13, 541-545.

Greenwald, G.S. (1967) Luteotropic complex of the hamster. Endocrinology 80, 118-130.

Greenwald, G.S. \& Rothchild, I. (1968) Formation and maintenance of corpora lutea in laboratory animals. J. Anim. Sci., Suppl. 1, 139-163.

Greenwald, G.S., Voogt, J.L. \& Limback, D. (1984) In vitro follicular and luteal steroidogenesis in the pregnant hamster with preliminary studies in the rat. Biol. Reprod. (in press).

Grinwich, D.L., Hichens, M. \& Behrman, H.R. (1976) Control of $\mathrm{LH}$ receptor by prolactin and prostaglandin $\mathrm{F}_{2 \alpha}$ in the rat corpora lutea. Biol. Reprod. 14, 212-218.

Hansel, W., Concannon, P.W. \& Lukaszewska, J.H. (1973) Corpora lutea of the large domestic animals. Biol. Reprod. 8, 222-245.

Harris, K.H., Murphy, B.D. \& Grinwich, D. (1981) Characteristics of luteal function in the superovulated, pseudopregnant hamster. Biol. Reprod. 25 , 699-707.
Hilliard, J. (1973) Corpus luteum function in guinea pigs, hamsters, rats, mice and rabbits. Biol. Reprod. 8, 203221 .

Jagannadha Rao, A., Madhwa Raj, H.G. \& Moudgal, N.R. (1972) Effect of LH, FSH and their antisera on gestation in the hamster (Mesocricetus auratus). $J$. Reprod. Fert. 29, 239-249.

Lee, C.Y., Tateishi, K., Ryan, R.J. \& Jiang, N.S. (1975) Binding of human chorionic gonadotrophin by rat ovarian slices: dependence on the functional state of the ovary. Proc. Soc. exp. Biol. Med. 148, 505-507.

Madhwa Raj, H.G. \& Moudgal, N.R. (1970) Hormonal control of gestation in the intact rat. Endocrinology 86, 874-889.

Morishige, W.K.Y. \& Rothchild, I. (1974) Temporal aspects of the regulation of corpus luteum function by luteinizing hormone, prolactin and placental luteotropin during the first half of pregnancy in the rat. Endocrinology 95, 260-274.

Mukku, V. \& Moudgal, N.R. (1976) Relative sensitivity of the corpus luteum of different days of pregnancy to LH-deprivation in the rat and hamster. Molec. cell Endocr. 6, 71-80.

Nutti, K.M., Sridharan, B.N. \& Meyer, R.K. (1975) Reproductive biology of PMSG-primed immature female rats. Biol. Reprod. 13, 38-44. 
Sala, G.B., Dufau, M.L. \& Catt, K.J. (1979) Gonadotropin action in isolated ovarian luteal cells. J. biol. Chem. 254, 2072-2083.

Shaha, C. \& Greenwald, G.S. (1982) In vivo and in vitro production of progestins by the corpus luteum of pregnancy of the hamster. Biol. Reprod. 26, 854-860.

Taya, K. \& Greenwald, G.S. (1981) In vivo and in vitro ovarian steroidogenesis in the pregnant rat. Biol. Reprod. 25, 683-691.

Tennant, J.R. (1964) Evaluation of the trypan blue technique for determination of cell viability. Transplantation 2, 685-694.
Terranova, P.F. \& Greenwald, G.S. (1979a) Antiluteinizing hormone: chronic influence on steroid and gonadotropin levels and superovulation in the pregnant hamster. Endocrinology 104, 1013-1019.

Terranova, P.F. \& Greenwald, G.S. (1979b) Antiluteinizing hormone: acute influence on steroid and gonadotropin levels and follicular development in the pregnant hamster. Endocrinology 104, 1020-1027.

Wiest, W.G. (1970) Progesterone and 20x-hydroxypregn4-en-3-one in plasma, ovaries and uteri during pregnancy in the rat. Endocrinology 87, 43-48.

Received 24 August 1983 